\title{
Os Pactos Sucessórios na História do Direito Português *.
}

\author{
Guitherme Braga da Cruz \\ Professor da Faculdade de Direito da Univer- \\ sidade de Coimbra e doutor "honoris causa" \\ pela Faculdade de Direito da Universidade de \\ São Faulo.
}

SUMÁrro: 1. Conceito, modalidades e estrutura jurídica dos pactos sucessórios. 2. A proibição dos pactos sucessórios no direito romano: a) Pactos de instituição de herdeiro; b) Pactos renunciativos; c) Pactos "de hereditate tertii". A constituição "De quaestione", de Justiniano. 3. Simpatia dos direitos europeus da alta Idade Média pela sucessão pactícia. Generalização da "instituição contratual" e dos "pactos renunciativos" 4. Embate da tradição costumeira com o direito romano renascido (sécs. XII e XIII). Solução de compromisso adoptada pelo "direito comum": a) Regra: Proibição genérica dos pactos sucessórios; b) Excepções: I. No domínio dos pactos "de hereditate tertii"; II. No domínio dos pactos "de succedendo"; III. No domínio dos pactos renunciativos. A decretal "Quamvis", de 1299. c) O caso especial dos pactos sucessórios estipulados nas convenções antenupciais. 5. Posição tomada pelo antigo direito português, quanto a validade dos pactos sucessórios em geral: a) Doutrina das Ordenações: I. Proibição dos pactos "de hereditate tertii" e "de succedendo" Validade dos primeiros, quando aprovados pelo "de cuius". Casos de duvidosa validade dos segundos. II. Validade dos pactos renunciativos, quando acompanhados de juramento. b) Movimento favorável à validade dos pactos sucessórios em geral, encabeçado por Melo Freire (séc. XVIII); c) Insucesso dessa tentativa

* Conferência proferida na Faculdade de Direito da Universidade de São Paulo, em 18 de agôsto de 1964. 
(séc. XIX). 6. Ampla aceitação dada pelo antigo direito português aos pactos sucessórios, quando efectuados nas convenções antenupciais. Modalidades de pactos mais generalizadas: a) Instituição contratual feita por um dos esposados em favor do outro ou por ambos recìprocamente; b) Instituição contratual feita por terceiros em favor dos esposados; c) Instituição contratual feita por esposados em favor de terceiros; d) Substituição contratual (fideicomissária ou vulgar); e) Promessa de igualdade ou pacto "de non meliorando"; f) Pacto de exclusão sucessória recíproca entre esposados; g) Renúncia da esposada à legítima paterna. 7. Os pactos sucessórios, sob a forma de "doações para casamento", no Código Civil Português de 1867.

1. Emprega-se a expressão "pacto sucessório", em sentido restrito, para designar a convenção ou contrato que tem por objecto a sucessão dum ou de ambos os contraentes. Em sentido amplo, porém, a expressão abrange não só as convenções que têm por objecto a sucessão dum dos contraentes como todo e qualquer contrato sôbre a herança duma pessoa viva.

Foram os romanistas da baixa Idade Média que pela primeira vez formularam um conceito de pacto sucessório e que sôbre êle fizeram uma tentativa de construção jurídica, que é ainda aquela dentro da qual hoje nos movemos. Assenta essa construção jurídica na classificação dos pactos sucessórios em três categorias fundamentais: pactos aquisitivos ou "de succedendo"; pactos renunciativos ou "de non succedendo"; e pactos sôbre a sucessão dum terceiro ou "de hereditate tertii".

a) O pacto aquisitivo ou "de succedendo" equivale ao que correntemente se denomina "instituição contratual", podendo revestir - como a instituição feita em testamento - as modalidades de instituição a título universal ou a título particular.

Se é feita a título universal, estamos perante uma "instituição contratual de herdeiro": um dos pactuantes institui herdeiro o outro, ou institui herdeiro um terceiro, ou 
faz com o outro uma instituição recíproca. Se é feita a título particular, estamos perante a figura do chamado "legado contratual".

Intrinsecamente, êstes pactos sucessórios aquisitivos têm uma natureza jurídica mista: como verdadeiros contratos inter vivos, são bilaterais e, em princípio, irrevogáveis; mas, como verdadeiros actos de direito hereditário ou sucessório, não transferem imediatamente um direito: criam apenas uma expectativa jurídica em favor do instituído, semelhante à expectativa dum herdeiro legitimário. Consequentemente, o instituidor não fica desde logo despojado do seu direito, mas sofre algumas limitações no respectivo exercício - que variam segundo os sistemas jurídicos - tendentes a proteger a expectativa do instituído. A mais expressiva dessas limitações, normalmente, é a de não poder fazer disposições a título gratuito, embora possa fazê-las a título oneroso.

b) O pacto renunciativo ou "de non succedendo" é aquele em que um dos contraentes renuncia à sucessão do outro. Apresenta, jurìdicamente, a mesma natureza mista do anterior: é um contrato, um acto jurídico bilateral, e, portanto, em princípio, irrevogável; mas é, ao mesmo tempo, um acto de direito hereditário ou sucessório, que, rigorosamente, não cria, nem extingue, nem transfere, de momento, qualquer direito. Pode, quando muito, extinguir uma expectativa juridicamente protegida, como, por exemplo, na renúncia à legítima, feita pelo herdeiro legitimário, ou na renúncia a uma instituição contratual, feita pelo instituído; mas pode nem isso sequer extinguir, como na simples renúncia a um direito sucessório "ab intestato", ou na renúncia a uma instituição testamentária de herdeiro. Essa, a razão por que deve rejeitar-se a denominação de "pactos extintivos", por vêzes impròpriamente dada aos pactos renunciativos ou "de non succedendo".

A renúncia que é objecto do pacto pode ser feita em favor duma pessoa certa e determinada ou ser uma renúncia pura e simples, sem indicação da pessoa beneficiada, entendendo-se, então, que é feita genèricamente em favor 
dos demais herdeiros presuntivos do de cuius. Duma maneira ou doutra, para haver verdadeiro pacto renunciativo è necessário que intervenha no acto a pessoa de cuja sucessão se trata e que o compromisso de renúncia seja assumido perante ela e por ela aceite. E, dai, esta dupla consequência :

- Se na renúncia intervém simplesmente o renunciante, não há nenhuma espécie de pacto: há uma renúncia unilateral e, portanto, livremente revogável pelo renunciante.

- Se a renúncia é pactuada com o beneficiário, mas sem a intervenção e aceitação da pessoa de cuja sucessão se trata, existe efectivamente um pacto, mas que não tem a natureza de "pacto renunciativo" ou "de non succedendo". Estamos, então, em face dum pacto "de hereditate tertii", visto que nele há simplesmente duas pessoas - renunciante e beneficiário -- que contratam entre si sôbre a sucessão de alguém que é alheio ao acôrdo feito.

c) Os pactos sôbre a sucessão dum terceiro ou "de hereditate tertii" constituem, justamente, a terceira e última categoria de pactos sucessórios. Na sua configuração típica, não cabem na categoria de pactos sucessórios stricto sensu, porque não se destinam a regular a sucessão dum dos contraentes: não são, numa palavra, actos de direito sucessório ou de direito hereditário; são actos bilaterais inter vivos (uma venda, uma renúncia, uma doação, etc.) efectuados entre dois interessados, acêrca da sucessão duma pessoa viva, que permanece estranha ao acôrdo celebrado.

Normalmente, porém, o pacto "de hereditate tertii" não se apresenta nesta forma pura, mas de mistura com o pacto aquisitivo e com o pacto renunciativo. É o que sucede sempre que nele intervém e dá o seu consentimento a pessoa sobre cuja sucessão o contrato incide. Se A, por exemplo, renuncia em favor de $B$ à sucessão de $C$, num contrato em que intervêm e dão o seu consentimento os três interessados, teremos desde logo entrelaçados, num mesmo e único acto contratual, as três modalidades de pactos su- 
cessórios que acabamos de apontar: entre o renunciante $\mathbf{A}$ e o de cuius $\mathrm{C}$, houve um pacto "de non succedendo"; entre o de cuius $\mathrm{C}$ e o beneficiário $\mathrm{B}$, houve um pacto "de succedendo"; e, entre o renunciante $A$ e o beneficiário $B$, houve um pacto "de hereditate viventis" ou "de hereditate tertii".

2. Para compreender a história dos pactos sucessórios nos direitos dos diferentes países europeus, é necessário conhecer prèviamente, nos seus traços essenciais, qual foi a posição adoptada pelo direito romano perante o problema da admissibilidade desses pactos, pois a doutrina romanística teve um peso decisivo, a partir do século XII, com o renascimento do direito romano, para a formação dos quadros dogmáticos em que se moveram, a este respeito, todos os direitos europeus da Baixa Idade Média e dos Tempos Modernos, até à Revolução Francesa.

O direito romano foi francamente hostil aos pactos sucessórios, embora não tenha chegado a formular, a esse propósito, qualquer construção jurídica. Não chegou a elaborar um conceito, nem muito menos uma classificação dos pactos sucessórios; e, por jsso mesmo, nunca chegou a formular, nem sequer na época justinianeia, uma proibição genérica dos pactos sobre sucessão futura. Neste, como em muitos outros domínios, o direito romano limitou-se a proceder casuisticamente: limitou-se a condenar, uma por uma, as várias modalidades possíveis de pactos, à medida que a prática se encarregava de as ir criando; e invocou fundamentos diversos, consoante os casos, para justificar essa condenação. E foi também casuìsticamente que condescendeu com a prática, acabando por admitir, na época post-clássica e justinianeia, algumas modalidades de pactos sucessórios que teimavam em não ceder perante a proibição. Assim :

a) Dos pactos de instituição de herdeiro não encontramos qualquer vestígio nas fontes romanas antes da época do Baixo Império. Compreende-se, aliás, que as fontes de direito da época clássica tenham guardado sobre eles abso- 
luto silêncio: a instituição dum herdeiro através dum contrato brigava de tal modo com os princípios fundamentais do direito sucessório romano, que devia ser uma hipótese de todo inédita; e, daí, que as fontes não refiram sequer essa hipótese, nem para a aprovar nem para a condenar.

$\mathrm{Na}$ época do Baixo Império, porém, devido sem dúvida à penetração de usos orientais, começaram a surgir no direito romano alguns casos concretos de instituição contratual, que obrigaram os imperadores a intervir e a fixar doutrina sobre a sua admissibilidade. É Diocleciano quem pela primeira vez toma posição no problema, através duma constituição imperial que depois seria reproduzida no Código de Justiniano. Consultado sobre a validade duma cláusula dum pacto dotal onde se convencionava, vice testamenti, que o marido, por morte da mulher, sucederia nos seus bens extra-dotais, o imperador declara que essa cláusula é de todo destituída de valor, porque é ofensiva da liberdade de testar, visto que a herança só se pode dar a estranhos por meio de testamento ("haereditas extraneis testamento datur") (C. 5, 14, 5).

A esta regra proibitiva - que, embora proferida sobre um caso concreto, tem valor de verdadeira proibição genérica - vamos encontrar apenas formulada uma possível excepção nas fontes romanas da mesma época: o "pactum mutuae successionis" de dois militares, referido como válido numa outra constituição do mesmo imperador Diocleciano e também depois reproduzida no Código de Justiniano (C. $2,3,19)$. É duvidoso, porém, se no caso figurado teria havido verdadeiro pacto sucessório ou simplesmente um testamento recíproco. Dum modo ou doutro, a hipótese é praticamente destituida de significado, porque, se se trata dum testamento recíproco, não envolve sequer excepção à regra, jả assinalada, da nulidade da instituição contratual de herdeiro; e, se se trata dum verdadeiro pacto, estamos em face duma excepção que não chega, nem pouco nem muito, para abalar a regra, dado o facto de os pactuantes 
serem militares e de o direito romano ter admitido, quanto a estes, um regime geral de direito sucessório à margem de todos os princípios.

Um ponto hoje muito discutido pelos romanistas é o de saber se esta hostilidade de direito romano contra a instituição contratual abrangeria apenas a instituição a título universal (instituição contratual de herdeiro) ou também a instituição a título particular (legado contratual). 0 que importa frisar a este respeito é que, tenha ou não havido uma hostilidade de princípio contra essa modalidade de pactos, o direito romano admitiu sempre, desde os tempos mais remotos até à época de Justiniano, a validade de certos negócios jurídicos que, se bem analisarmos, implicam ou podem implicar, directa ou indirectamente, uma instituição contratual a título singular. Tal é, no antigo direito, o caso da mancipatio familiae mortis causa; no direito clássico, o caso do pactum de lucranda dote; e, no direito justinianeu, a stipulatio post mortem e o mandato post mortem.

b) Relativamente aos pactos renunciativos, aparecem já na época clássica alguns textos a condená-la expressamente. Vê-se, pois, que o seu uso começou a difundir-se mais cedo no Império Romano do que o dos pactos de instituição de herdeiro, o que não é de admirar se nos lembrarmos de que não brigavam tão ostensivamente como estes com os principios do direito sucessório romano.

O caso mais frequentemente citado e condenado nas fontes - e que devia, portanto, ser o mais vulgarizado e o da renúncia da filha dotada à herança paterna. A hipótese aparece já prevenida e condenada num texto de Papiniano, com o fundamento de que as convenções dos particulares não podem prevalecer sobre a autoridade das leis ("privatorum enim cautiones legum auctoritate non censeri") (D. $38,16,16)$; e é novamente referida e condenada numa constituição de Alexandre Severo, mais tarde reproduzida no Código de Justiniano (C. 6, 20, 3). 
Há textos que igualmente condenam a renúncia ao direito de intentar, após a morte do testador, a querela inofficiosi testamenti (P.S., 4, 5, 8; C. 3, 28, 35, 2) e a renúncia ao direito de reclamar a quarta Falcidia (D. 35, 2, 15, 1); e o motivo invocado é, mais uma vez o de que as convenções privadas não podem derrogar as leis de ordem, pública como são as que regulam as sucessões.

c) Os pactos "de hereditate tertii", finalmente, são já objecto de condenação casuística na época clássica, a propósito da venda (D. 18, 4, 1), da doação (D. 39, 5, 29, 2) e da aceitação duma sucessão não aberta (D. $28,6,2,2)$; e acabam por ser proibidos, em termos genéricos, logo nos começos do Baixo Império, através duma constituição de Constantino, mais tarde incluída no Código Teodosiano (C. Th., $2,24)$.

No mais antigo destes textos, que é o referente à venda duma sucessão não aberta, invoca-se como fundamento da nulidade do pacto a sua falta de objecto ("qui in rerum natura non sit quod venierit"); mas, em todos os demais textos, a razão que invariàvelmente passa a ser invocada é a de estes pactos serem desonestos ("improba") e contrários aos bons costumes ("contra bonos mores").

Duas excepções, contudo, são previstas nos textos a esta proibição genérica: uma delas, admitida já desde a época clássica, é a da "societas omnium bonorum", ou seja, a sociedade em que os sócios se obrigam a pôr em comum todos os seus bens presentes e futuros, o que implica, como é evidente, um acordo sobre a sucessão de terceiros (D. 17, $2,3,1)$; a outra, consagrada justamente pela constituição de Constantino que estabeleceu a proibição genérica destes pactos, é a partilha da herança materna feita pelos filhos em vida da mãe, desde que esta dê o seu consentimento e nele persevere até a morte.

Foi esta a doutrina que, devidamente generalizada, veio a obter consagração definitiva no direito justinianeu. Respondendo a uma consulta dos advogados de Cesareia sobre 
a validade duma convenção celebrada entre vários herdeiros presuntivos dum terceiro, o Imperador, numa constituição datada de 531, declara nulas todas estas convenções, com o fundamento de que, além de contrárias aos bons costumes, são odiosas e cheias de tristíssimas e perigosas consequências ("odiosae videntur et plenae tristissimi et periculosi eventus") (C. 2, 3, 30). Invoca-se assim, pela primeira vez, como fundamento da nulidade dos pactos sobre a sucessão dum terceiro, o facto de representarem um perigo para a vida da pessoa de cuja sucessão se trata, na medida em que assentam na condenável esperança ("acerbissima spes") da sua morte próxima. É aquilo a que, alguns séculos mais tarde, os comentadores chamariam "votum mortis" e que seria, ao longo dos tempos, o argumento mais largamente usado contra a admissibilidade dos pactos sucessórios.

Desta fundamentação, tira Justiniano uma consequência lógica: a convenção sobre a sucessão dum terceiro deixa de ser imoral e de representar um perigo para a vida do de cuius se este der o seu expresso consentimento e se perseverar nesse consentimento até à morte ("si voluntatem suam eis accommodaverit et in es usque ad extremum vitae spatium perseveraverit"). É a mesma doutrina, como se vê, que a constituição de Constantino tinha estabelecido para o caso concreto da partilha da herança materna feita pelos filhos em vida da mãe, agora generalizada a todos os casos de pactos sobre a sucessão dum terceiro.

Esta constituição de Justiniano, conhecida vulgarmente, das suas primeiras palavras, por constituição De quaestione, veio a constituir, após o renascimento do direito romano, um dos pilares fundamentais da teoria dos pactos sucessórios, em todos os países europeus.

3. A contrastar com este desfavor de que foram objecto por parte do direito romano, os pactos sucessórios vão encontrar em toda a Europa ocidental, a partir das invasões germânicas, terreno propício para proliferar. 
a) A decadência e desaparecimento do testamento romano, que se verificou em todas as antigas províncias do Império do Ocidente entre o séc. V e o séc. VIII, favoreceu a generalização de vários sucedâneos — uns de origem germânica, outros de origem romano-vulgar e outros, ainda, nascidos das práticas costumeiras medievais - tendentes a resolver o problema da devolução voluntária da sucessão. Tal é o caso da affatomia e das hereditoriae, do direito franco; do thinx, do direito lombardo; das adfiliationes, usadas em diversas regiões da Itália; e das perfiliationes, correntes na prática jurídica dos Reinos hispânicos da época da Reconquista cristã, após as invasões muçulmanas; e tal é também o caso das chamadas doações post obitum, conhecidas e largamente difundidas, quase por igual, em todos os países da Europa na Alta Idade Média.

Todos estes sucedâneos do testamento têm natureza contratual e têm por objeto regular, duma forma directa ou indirecta, no todo ou em parte, a sucessão dum dos contraentes, revestindo assim - de forma mais ostensiva ou de forma mais velada, segundo os casos - a natureza de verdadeiros pactos sucessórios. E é sabido que algumas dessas figuras jurídicas não desapareceram - antes continuaram a ter larga aceitação prática - depois do renascimento e difusão do testamento. Foi o que sucedeu, designadamente, com as doações post obitum, forma de contrato sucessório com a qual, aliás, se tinham fundido algumas das outras figuras jurídicas que indicámos, conhecidas pelo nome genérico de adoptiones in hereditatem.

Seria precipitado, no entanto, pretender encontrar nas doações post obitum ou em alguma das modalidades de adoptio in hereditatem a origem histórica exclusiva da instituição contratual, que vamos encontrar difundida em todos os países ocidentais da Europa, como figura jurídica pujante e de contornos bem definidos, a partir de fins do séc. XII e, sobretudo, a partir do séc. XIII. 
As teses que se têm sustentado sobre as origens da instituição contratual nos direitos europeus da Baixa Idade Média pecam quase todas por essa preocupação de exclusividade, na medida em que pretendem fazĉ-la derivar concretamente das odoptiones in hereditatem, das cartas de enfeudação ou das doações post obitum, podendo dizer-se, por isso mesmo, que estamos em face dum problema histórico que se encontra ainda muito longe de ser esclarecido.

Em nosso entender, tudo quanto se pode afirmar, no estado actual das investigações, é que a instituição contratual, independentemente de qualquer filiação concreta, se generalizou com base em duas forças propulsoras fundamentais: em primeiro lugar, a ideia de que a sucessão se pode regular por meio de contrato - ideia fortemente enraizada, à custa da intensa divulgação obtida nos séculos anteriores pelas adoptiones in hereditatem e pela doação post obitum; e, em segundo lugar, o favor dispensado nesta època a todas as instituições jurídicas tendentes à manutenção da integridade do património familiar e à conservação dos bens nas familias, através das gerações. Sob este último aspecto, a instituição contratual, tal como se apresenta em todos os países da Europa latina na Baixa Idade Média, pode considerar-se o produto dum ambiente social específico: do mesmo ambiente social que permitiu - não só em França, como na Itália, na Espanha e em Portugal a proliferação de instituições jurídicas tendentes a evitar a -desagregação do património familiar, como a laudatio parentum, o retracto familiar, a reserva hereditária, a regra paterna paternis ou direito de troncalidade e a regra da exclusão sucessória dos ascendentes relativamente aos bens de procedência familiar (propres ne remontent).

b) $\mathrm{O}$ que acabamos de dizer sobre a instituição contratual pode repetir-se, mutatis mutandis, dos pactos sucessórios renunciativos, acolhidos com a mais franca simpatia por todos os direitos costumeiros da Europa ocidental desde o séc. XII e, sobretudo, a partir do séc. XIII. 
Também aqui parecem de rejeitar as teses exclusivistas, que pretendem filiar as renúncias a sucessão futura no direito germânico ou no direito feudal, ou que as consideram um simples resultado de práticas costumeiras. Tudo quanto de positivo se pode dizer, no estado actual das investigações, é que a aceitação generalizada das renúncias contratuais na baixa Idade Média encontrou sem dúvida o terreno preparado por certas instituições juridicas dos séculos anteriores, como a exclusão sucessória das filhas dotadas; mas não contribuiu menos para a generalização desses pactos - tal como há pouco frisámos quanto à instituição contratual - o favor dispensado pela sociedade da época a todas as instituições jurídicas que favoreciam a conserviação dos bens nas famílias.

4. Esta larga aceitação dada aos pactos sucessórios por todos os direitos costumeiros da Europa Ocidental nos sćcuios XII e XIII iria, no entanto, encontrar pela frente a tenaz resistência dum novo e importante acontecimento da história jurídica européia da mesma época : o renascimento do direito romano; e do embate entre as práticas costumeiras e as novas idéias romanísticas iria justamente resultar um conjunto de soluções de compromisso que fixariam o rumo dos vários direitos europeus, nesta matéria, até ao fim do Ancien Régime e à elaboração dos códigos individualistas do século XIX.

Deve-se aos romanistas desta época, antes de mais nada - e conforme já atrás assinalámos - , a formulação do conceito de pacto sucessório, abrangendo nessa expressão, em termos gerais, todo e qualquer acordo sobre a sucessão duma pessoa viva. A eles se deve, igualmente, a classificação dos pactos sucessórios nas três categorias fundamentais que já devidamente caracterizámos: pactos aquisitivos ou de succedendo, pactos renunciativos ou de non succedendo e pactos sobre a sucessâo dum terceiro ou de hereditate tertii. $\mathrm{E}$ a eles se deve ainda, finalmente, a constru- 
ção duma teoria geral dos pactos sucessórios, que o velho direito romano nunca tinha chegado a elaborar.

Assenta essa teoria geral numa regra: a de que todos os pactos sobre a sucessão duma pessoa viva são, em princípio, proibidos e feridos de nulidade. E completa-se essa regra com várias excepções, ora apoiadas directamente nos textos romanos, ora impostas pela necessidade de transigir com as práticas costumeiras.

a) A regra de que os pactos sucessórios são, em princípio, proibidos e feridos de nulidade vão os romanistas desta época sobretudo buscá-la à famosa constituição $D e$ quaestione, do imperador Justiniano. Embora esta constituição se refira restrita e concretamente, conforme vimos, aos pactos de hereditate tertii - e não à instituição contratual, nem aos pactos renunciativos --, ela é sempre tomada agora pelos romanistas como uma proibição de ordem genérica de todos os pactos sucessórios. E a razão que nela se invoca - o facto de tais pactos implicarem um "votum mortis" e, portanto, um perigo para a vida do de cuius - é agora apresentada pelos romanistas como justificação da nulidade de todos os pactos sobre a sucessão duma pessoa viva.

Isto não os impede, porém, de citar outros textos e invocar outras razões para justificar concretamente a proibição das renúncias contratuais e dos pactos de succedendo. Á nulidade das renúncias fundamentam-na eles, normalmente, no facto de serem contrários às normas de ordem pública; e a nulidade da instituição contratual, no facto de esta constituir uma condenável limitação à liberdade de testar.

b) I - No domínio das excepções a esta proibição genérica dos pactos sucessórios, são desde logo significativas as que os romanistas então aceitam a propósito dos pactos de hereditate tertii: - Alguns deixam-se influenciar pelas práticas costumeiras até ao ponto de sustentarem a validade, em termos amplos, de todos e quaisquer pactos sobre a sucessão dum terceiro, procurando apoiar-se no 
texto romano, já nosso conhecido, que considera válida, sem: reservas, a societas omnium bonorum (D. 17, 2, 3, 1). Mas: a maior parte não vai tão longe: limita-se a aceitar como excepção ao princípio da nulidade destes pactos aquela que se acha consignada expressamente na constituição $D e$ quaestione, ou seja, que os pactos de hereditate tertii são vá-. lidos se o de cuius dá o seu consentimento e nele persevera: até a morte.

II - No que respeita aos pactos de succedendo, condescendem os romanistas em admitir duas excepções à regra da proibição genérica dos pactos sucessórios. A primeira é a que respeita à validade do pacto conhecido pela denominação de promessa de igualdade, ou seja, o pacto pelo qual um ou ambos os pais prometem a um dos filhos não criar para os restantes uma siluação de favor na respectiva sucessão. Este pacto, que era expressamente declarado nulo por uma constituição imperial romana do ano 259, mais tarde incluída no Código de Justiniano (C. 2, 3, 15), tinha ảepois sido considerado válido por uma constituição de fins do séc. IX ou começos do séc. X (886-912), do imperador bizantino Leão, o Filósofo (Nov. Leon. 19), que foi acrescentada, com outras novelas do mesmo imperador, às Novelas de Justiniano, nas versões medievais e modernas do Corpus Iuris Civilis. Os romanistas invocam agora essa constituição para sustentar que a promessa de igualdade não é abrangida pela proibição dos pactos sucessórios.

A segunda excepção é a que respeita à validade da instituição contratual a titulo singular, a que certos autores modernos dão o nome de legado contratual. Esta excepção à proibição genérica dos pactos de succedendo é introduzida: por Bártolo (ad leg. 61, D. 45, 1) e representa, manifesta-. mente, da parte deste eminente jurisconsulto, uma espécie: de concessão às exigências resultantes das práticas costu-meiras. Como a razão invocada para justificar a nulidade: da instituição contratual é a da limitação que essa espécie de pacto impóe à liberdade de testar, Bártolo - logo seguido da generalidade dos romanistas da época - sustenta 
que só devem ser feridas de nulidade as instituições contratuais de herdeiro, isto é, as instituições a título universal, mas não as instituições contratuais que incidem sobre uma res singularis, visto que estas não retiram totalmente ao de cuius a sua liberdade de testar.

III - Onde mais fortemente se verifica, porém, a impotência dos romanistas para resistir à simpatia generalizada obtida pelos pactos sucessórios nos direitos costumeiros medievais, é no que toca às renúncias a uma futura sucessão.

As razões romanisticas invocadas para justificar a nulidade destes pactos eram demasiado débeis para opor barreira à aceitação indiscutida que tinham na prática. E daí que os jurisconsultos da época, em vez de insistirem inùtilmente na sua total rejeição, acabem por procurar antes encontrar expedientes capazes de validar as renúncias contratuais perante o próprio direito comum.

Um desses expedientes - que parece ter sido sugerido pela primeira vez pelo glosador Placentino - era o de fazer acompanhar de juramento a declaração do renunciante. Dado o geral respeito que merecia nesta época o juramento, estaria aí um meio fácil de dar validade a um acordo que se considerava, em princípio, proibido, tanto mais que esta espécie de pactos sucessórios não podia tão fàcilmente como as demais apodar-se de imoral ou de perigosa para a vida do de cuius.

Outro expediente - aconselhado pelo próprio Acúrsio na Glosa, depois de manifestar a sua discordância em relaçáo ao juramento - era o de o pacto ser efectuado, não entre o renunciante e o de cuius, mas entre o renunciante e o beneficiário, intervindo o de cuius apenas para dar o seu consentimento (C. 6, 20, 3, gl. "improbatur"). O pacto deixava, desta forma, de ser uma renúncia contratual em sentido estricto, para passar a ser um pacto de hereditate tertii, válido dentro das condições previstas pela constituição De quaestione. 
Este segundo expediente oferecia, contudo, o inconveniente de o de cuius poder retirar a todo o tempo o seu consentimento, ficando o pacto sem nenhum efeito. E, por êsse motivo - e também pelo apoio que lhe davam os canonistas -, foi o expediente do juramento que obteve maior aceitação prática, acabando por obter expressa consagração numa decretal de 1299, do papa Bonifácio VIII - a famosa decretal Quamvis -, a propósito do caso concreto da renúncia das filhas dotadas à herança paterna, que era, de resto, o caso de longe mais frequente de pactos renunciati$\operatorname{vos}$ (in VI. $.^{\circ}, 1,18,2$ ).

Estabeleceu, com efeito, essa decretal que, embora pela lei civil (isto é, pelo direito romano) seja nulo o pacto celebrado entre o pai e a filha dotada, em que esta, declarando-se satisfeita com o dote, renuncia à futura sucessão paterna, deve o mesmo pacto inteiramente observar-se (omnino observari), se fôr confirmado por um juramento prestado sem dolo nem violência, porque tal juramento não atenta contra a salvação eterna de quem o faz nem redunda em prejuizo de outrem ("cum non vergat in aeternae salutis dispendium, nec redundet in alterius detrimentum").

c) Não ficaram por aqui, no entanto, as concessões feitas pelos romanistas e pelos canonistas às práticas costumeiras favoráveis aos pactos sucessórios. Além destas diversas excepções, formuladas concretamente a propósito de cada um dos três tipos fundamentais do pactos sucessórios e integradas na respectiva teoria gcral, acabaram os juristas do direito comum por admitir uma nutra excepção de carácter genérico, que viria a ter muito maior vulto e significado do que qualquer das já apontadas: a da validade, em têrmos amplos, de tôdas e quaisquer convenções feitas nos contratos ante-nupciais, desde que não fôssem contrárias à moral nem às leis de ordem pública.

Sob a pressão das idéias nobiliárquicas e das práticas costumeiras, os jurisconsultos - mesmo os de mais arreigada formação romanistica — viram-se obrigados a ceder progressivamente terreno neste ponto; e, nos começos do 
séc. XVI, a aceitação generalizada dos pactos sucessórios nos contratos antenupciais tinha já adquirido foros de autêntico dogma jurídico em todos os países da Europa ocidental. Os contratos antenupciais, que revestiam ao tempo a natureza de verdadeiros pactos de família, eram o terreno ideal para a estipulação da mais variada gama de arranjos sucessórios tendentes a manter o lustre das famílias e a conservação da integridade das fortunas através das gerações. E, por isso mesmo, a hostilidade romanística aos pactos sucessórios rendia-se aqui totalmente perante o argumento do favor matrimonii, aceitando em têrmos gerais a validade dos pactos celebrados nesse momento pelos es. posados entre si, ou entre êles e os seus familiares.

5. O quadro que acabamos de descrever foi o modelo a que se adaptaram - com diferenças de pormenor, de caso para caso - os sistemas jurídicos de quase todos os países onde o renascimento do direito romano encontrou pela frente a resistência de tradições costumeiras fortemente arreigadas. E Portugal não podia fazer excepção a essa regra.

Tal como noutros países da Europa, também em Portugal a história dos pactos sucessórios se vai desenrolar, desde o séc. XV até ao séc. XIX, dentro de dois mundos quase independentes: a um lado, uma teoria geral dos pactos sôbre sucessão futura, aplicável à generalidade dos casos, tomando como regra a respectiva condenação e admitindo algumas excepções a essa regra, concreta e taxativamente fixadas; a outro lado, constituindo um verdadeiro mundo à parte, o domínio das convenções matrimoniais, onde se permite a livre proliferação das mais diversas modalidades de pactos sucessórios, quer dos esposados entre si, quer dêstes com terceiros.

Analisemos, primeiramente, a posição tomada pelo direito português no domínio da teoria geral dos pactos sôbre sı!cessão futura: 
a) Portugal foi sem dúvida o primeiro país da Europa cuja legislação geral tomou posição sôbre o problema da admissibilidade dos pactos sucessórios. Com efeito, já as Ordenações Afonsinas, em meados do séc. XV (1446), contêm duas leis referentes ao assunto (IV, 62,6), que depois seriam transcritas nas Ordenações Manuelinas, de 1521 (IV, 44, 2 e 3), e nas Filipinas, de 1603 (IV, 70, 3 e 4), mantendo-se assim em vigor até à promulgação do Código Civil, na segunda metade do séc. XIX. A primeira dessas duas leis condena os pactos de succedendo e de hereditate tertii; a segunda, condena em princípio os pactos renunciativos, mas considera-os válidos quando acompanhados de juramento.

I - A primeira lei refere separadamente o pacto em que "alguém promete a outrem fazê-lo herdeiro em parte ou no todo" e o "contrato sôbre a herança de algum vivente"; mas abrange-os numa condenação única, com o fundamento de que são "contratos torpes", e de que "são contra o direito comum e reprovados por êle em tal guisa que não podem ser confirmados por juramento".

Como a lei nada mais dizia senão isto, foram os jurisconsultos que tomaram a seu cargo fixar o verdadeiro sentido desta ampla proibição, admitindo desde logo uma importante excepção ao preceito legal quando aos pactos de hereditate tertii: êsses pactos seriam válidos dentro das condições previstas pela constituição De quaestione de Justiniano, isto é, tendo o de cuius dado o seu consentimento e nele perseverando até à morte. Como a lei fundamentava a proibição desses pactos no facto de serem contrários ao direito comum, era fácil aos nossos jurisconsultos invocar êsse mesmo direito comum para justificar uma tal excepção.

No que diz respeito à instituição contratual, os jurisconsultos portugueses tomavam a proibição legal bastante ao pé da letra, frisando que ela abrangia tanto a instituição na totalidade como numa quota parte da herança e que a instituição não deixaria de ser nula pelo facto de ser feita 
em favor duma pia causa, ou de ser feita pelo pai em favor dos filhos, ou de revestir a natureza de instituição fideicomissária ou de instituição recíproca.

Levantavam dúvidas os nossos juristas, tão sòmente, quanto à validade da instituição contratual a título particular e quanto à validade da instituição feita em favor dum casamento certo e determinado, mas fora do contrato antenupcial. Quanto ao primeiro problema, as opiniões andaram sempre divididas, mas um importante sector da doutrina defendia, na esteira de Bártolo, que a instituição contratual sôbre uma res singularis não era abrangida pela proibição legal, pois não privava totalmente o instituidor da sua liberdade de testar. E quanto ao segundo problema, acabou por prevalecer a opinião de que a instituição contratual feita em favor de um ou ambos os esposados com vista ao seu casamento, assim como era lícita quando estipulada no próprio contrato antenupcial, igualmente o seria quando feita em acto à parte.

II - A lei referente aos pactos renunciativos prevê expressamente as duas hipóteses de o contrato ser feito entre o renunciante e o beneficiário ou entre o renunciante e o de cuius e dectara que êsses contratos, embora sejam considerados "contra o direito" (isto é, contra o direito romano), podem no entanto ser confirmados por juramento, "por não serem tão reprovados como os outros".

$\mathrm{Na}$ interpretação desta lei, porém, a maioria dos jurisconsultos recusava-se a aceitar que o pacto renunciativo feito simplesmente entre o renunciante e o beneficiário pudesse ser confirmado por juramento. É que a renúncia, efectuada sob essa forma, revestia a natureza dum verdadeiro pacto de hereditate tertii, que já a lei anterior declarara nulo e insusceptivel de confirmação por juramento. A única maneira de validar uma renúncia feita nessas condições seria a que se preconizava em geral para os pactos de hereditate tertii, ao abrigo da constituição De quaestione: dar o de cuius o seu consentimento e não voltar a tirá-lo. 
até à morte. Mas, respeitadas estas condições, o pacto seria válído, como qualquer outro pacto sôbre a herança dum terceiro, independentemente de ter sido ou não confirmado por juramento, devendo ter-se por supérflua a referência que nesse sentido se encontrava na lei.

A respeito da segunda hipótese figurada na lei, já a referência ao juramento era perfeitamente cabida: sendo a renúncia pactuada directamente entre o renunciante e o de cuius, a sua validade ficaria dependente do facto de ser acompanhada ou não de juramento.

Havia aqui manifesta influência, que a própria lei não ocultava, da doutrina da Decretal Quamvis, do papa Bonifácio VIII, a que já atrás nos referimos. Mas a lei portuguesa sôbre as renúncias contratuais tinha um campo de aplicação mais vasto, pois não abrangia apenas a renúncia da filha dotada à sucessão paterna, como a famosa decretal de 1299 , mas tôda e qualquer renúncia a uma sucessão futura, independentemente da contrapartida da concessão dum dote. Tal era designadamente o caso, muito frequente, da renúncia à herança paterna feita pelo filho ou filha por motivo duma profissão religiosa.

$\mathrm{O}$ que o nosso direito, em contrapartida nunca dispensou -- ao contrário do que sucedeu em certos direitos estrangeiros, como o direito francês - foi a exigência do juramento como condição sine qua non da validade da renúncia, tendo resultado vãs as tentativas de alguns jurisconsultos para considerar supérfluo êsse requisito.

Em complemento da disposição legal, fixavam os jurisconsultos portugueses várias regras acerca dos pactos renunciativos, que não diferiam, aliás, das perfilhadas pela doutrina estrangeira acerca do mesmo assunto. Assim:à semelhança do disposto na decretal Quamvis, entendia-se que a renúncia seria nula se fôsse extorquida por meio de dolo, violência ou lesão; noutra ordem de considerações, entendia-se que, embora válida, a renúncia caducaria e ficaria sem nenhum efeito pela predefunção da pessoa em 
cujo favor concretamente tivesse sido feita, ou pelo facto de o renunciante ter sido de novo chamado à sucessão pelo de cuius, ou pelo falecimento do renunciante em vida do de cuius deixando descendência, a menos que a declaração de renúncia tivesse sido feita por si e por seus descendentes; e, finalmente, reconhecia-se que a renúncia a uma sucessão não abrangia o direito a alimentos nem o direito que o renunciante pudesse ter a certos bens do de cuius a um outro título diferente da sucessão, ou por sucessão indirecta, através dum terceiro.

b) A teoria geral dos pactos sucessórios do antigo direito português, tal como acabamos de apresentá-la, iria sofrer uma séria tentativa de remodelação na segunda metade do séc. XVIII, que, no entanto, não foi coroada de êxito, apesar da grande autoridade do jurisconsulto que a lançou: o famoso professor da Universidade de Coimbra, Pascoal José de Melo Freire.

Seduzido pelas idéias de "usus modernus pandectarum", francamente favoráveis aos pactos sucessórios, Melo Freire procurou defender a tese, verdadeiramente revolucionária, de que êsses pactos deviam ser admitidos sem quaisquer limitações: - Os pactos renunciativos e de hereditati tertii seriam sempre válidos, sem necessidade de se lhes acrescentar qualquer cláusula penal, ou qualquer consentimento do de cuius, ou qualquer juramento, pormenores que em seu entender nada acrescentavam nem diminuiam ao acordo sucessório em si mesmo considerado; e os pactos de succedendc seriam igualmente válidos, sem quaisquer limitações, por serem completamente destituídas de sentido as razões invocadas contra êles pelo direito romano. Em todo o caso, êstes pactos de succedendo, dada a sua semelhança com os actos de última vontade, deveriam considerar-se livremente revogáveis pelo instituidor.

Melo Freire reconhecia que êste seu ponto de vista era contrário à letra expressa das nossas leis; mas resolvia a dificuldade considerando os respectivos preceitos revogados pela lei de 18 de Agôsto de 1769 - a mais tarde denominada 
Lei da Boa Razão -, atendendo a que não tinham fundamento na recta ratio nem nas tradições pátrias, mas apenas em institutos privativos dos romanos.

c) Mas a nova tese, como é natural, não vingou. Se o "usus modernus pandectarum" favorecia os pactos sucessórios, o individualismo nascido da Revolução Francesa fazia soprar contra êles novos ventos adversos; e os nossos escritores da primeira metade do séc. XIX, na impossibilidade de condená-los em têrmos mais amplos, procuravam, ao menos, não consentir a sua generalização, agarrando-se aos textos das Ordenações para condenarem, com base neles, a doutrina propugnada por Melo Freire.

$\mathrm{E}$ assim, nas vésperas da promulgação do Código Civil, o direito vigente em Portugal acerca dos pactos sucessórios em geral era ainda o mesmo que os nossos velhos jurisconsultos tinham fixado com base nas duas leis referentes ao assunto, contidas nas Ordenações: nulidade dos pactos de succedendo, excepção feita da instituição contratual em favor dum casamento certo e determinado; nulidade dos pactos de hereditate tertii, excepto dentro das condições concretamente previstas na lei De quaestione de Justiniano; e admissibilidade das renúncias contratuais, quando acompanhadas de juramento.

6. Para o efeito da celebração de pactos sucessórios, as convenções matrimoniais constituíam, como já dissemos, um mundo à parte. À semelhança do que sucedeu noutros direitos europeus, designadamente no direito francês, também no direito português se estabeleceu - desde data que não é possível precisar com segurança, mas, pelo menos, ảesde o séc. XVI - o verdadeiro dogma jurídico de que os princípios gerais referentes à proibição dos pactos sucessórios não tinham aplicação no domínio dos contratos antenupciais.

Os nossos antigos jurisconsultos justificavam êsse ponto de vista com base no princípio da liberdade das convenções matrimoniais, que já as Ordenações Manuelinas, nos come- 
ços do séc. XVI, expressamente estipulavam (IV, 7, pr.) e que as Ordenações Filipinas depois reproduziram (IV, 46 , pr.).

Tal como êsse princípio se encontrava redigido nas Ordenações, é juridicamente muito duvidoso se poderia comportar uma interpretação tão lata; mas a verdade é que o argumento era aceite sem discrepâncias, pois permitia dar acolhimento a uma doutrina que gozava de franca simpatia e que, ainda para mais, se via defendida nas obras mais divulgadas da literatura jurídica estrangeira.

A partir de meados do séc. XVIII, os autores passaram também a invocar, como argumento em favor da mesma doutrina - ou até como sua confirmação - uma lei de $17 \not ̉ 1$, onde expressamente se dizia que as mulheres, "como senhoras das suas Casas, podem estipular com seus respectivos esposos, assim para a vida como para a morte, as reservas e condições que bem lhes parecer, como até agora se praticou sem a menor diferença" (lei de 17-VIII-1761, $\left.\S 8 .^{\circ}\right)$.

A liberdade das convenções matrimoniais era, assim, aceite pela doutrina no mais amplo sentido, considerando-se válidas tôdas as estipulações e cláusulas que os esposados resolvessem convencionar, desde que não fossem ofensivas dos bons costumes nem das leis de interesse e ordem pública; e, através dessa larga porta, dava-se livre ingresso nos contratos de casamento a uma grande variedade de pactos sucessórios, cuja validade, de outra forma, seria normalmente rejeitada.

Num ponto estavam de acôrdo ainda todos os juristas a respeito destes pactos sucessórios celebrados nas convenções matrimoniais: é que a sua eficácia - como, aliás, a do próprio contrato de que faziam parte integrante - ficava dependente da válida celebração do casamento na prerisão do qual a convenção havia sido efectuada. Caducavam, portanto, se êsse casamento não chegasse a efectuar-se ou se viesse a ser declarado nulo. 
Vejamos quais eram os principais exemplos de pactos sucessórios praticados nas convenções antenupciais:

a) Um dos mais frequentes era o da instituição contratual, quer a título universal quer a título particular, feita por um dos esposados em favor do outro ou por ambos reciprocamente.

Normalmente, estes pactos eram recíprocos, a título universal, e feitos sob a condição de não haver descendentes do casamento no momento da sua dissolução. Mas os autores acentuavam que seriam igualmente válidos quando feitos apenas por um dos esposados em favor do outro e quando incidissem sôbre bens certos e determinados (legado contratual). Também não era forçoso fazê-los depender da condição da inexistência de descendentes, cuja legítima, aliás, não tinha então sequer que ser respeitada. É que a sucessão dos descendentes do casal, verdadeiramente, não ficava prejudicada com êste pacto; ficava simplesmente adiada para o momento da morte do cônjuge sobrevivo. $\mathrm{O}$ que tinha de respeitar-se, evidentemente, era a legitima dos descendentes de anterior matrimónio e a legítima dos ascendntes do instituidor.

b) Frequente era também a instituição contratual feita no contrato de matrimónio, não já pelos esposados em favor um do outro, mas por parentes ou por terceiros em seu benefício. Tal como a anterior, podia ser a título universal ou incidir sobre uma res singularis; mas, diferentemente dela, tinha de respeitar sempre na íntegra os direitos dos herdeiros legitimários do instituidor.

c) Menos vulgar, mas considerada também pelos autores como inteiramente válida, era a instituição contratual feita pelos esposados em favor de terceiros. Era usada esta modalidade de pacto sucessório, quer para dispor em favor de terceiros da totalidade da sucessão, na previsão de o casamento se dissolver sem descendência, quer para beneficiar terceiros por conta da quota disponível. Duma maneira ou de outra, o contrato não podia ferir os direitos dos herdeiros legitimários do instituidor. 
Embora os autores sejam pouco explícitos a êsse respeito, parece que, nesta modalidade de pactos, se a instituição era feita em favor de pessoas indeterminadas (por exemplo, os parentes, em geral, ou os herdeiros legítimos, sem especificação), ou em favor de pessoas determinadas que não intervinham no acto, tinha valor puramente testamentário; e só revestiria natureza contratual e irrevogável sendo feita em favor de pessoas certas e determinadas que tinham intervindo no contrato matrimonial e nele dado a sua aceitação.

d) Todas estas modalidades de instituição contratual feitas nas convenções matrimoniais, quer pelos esposados entre si, quer por terceiros em favor dos esposados, quer pelos esposados em favor de terceiros, eram frequentemente acompanhadas de substituições fideicomissárias ou de substituições vulgares, que constituíam, assim, mais uma categoria de pactos sucessórios, cuja licitude, neste domínio, ninguém punha em dúvida: a das substituições contratuais.

Eram utilizadas, fundamentalmente, para beneficiar os descendentes dos instituídos, atribuindo-lhes o direito de suceder a êstes (substituição fideicomissária) ou o direito de suceder directamente ao instituidor, no caso de o instituido morrer antes dele (substituição vulgar).

$\mathrm{Na}$ instituição contratual feita por terceiros em favor dos esposados pressupunha-se, mesmo, existente uma substituição vulgar tácita, em favor dos descendentes nascidos do casamento em vista do qual a instituição tinha sido feita. Dêste modo, a instituição não caducaria pelo simples pre¿ecesso do instituído, entendendo-se que beneficiariam directamente dela, nesse caso, os respectivos descendentes.

e) Outro pacto a que fazem referência os nossos antigos jurisconsultos é a promessa de igualdade ou pacto "de non meliorando", que consistia na promessa feita pelo pai, no contrato de casamento dum dos filhos, de não utilizar a sua quota disponível em favor de nenhum dos restantes. 
Esta promessa podia apresentar-se sob a forma duma iristituição contratual feita pelo pai, por ocasião do casamento dum filho, em favor de todos os filhos por igual. Mas, normalmente, tal não sucedia. A promessa era simplesmente a de não melhorar os restantes filhos, o que, portanto, não impedia o declarante de utilizar a sua quota disponivel em favor do próprio filho-promissário, ou para realizar legados pios.

f) Muito correntes também entre nós eram os pactos tendentes a evitar que, por via do casamento, se operasse uma mudança de linha familiar dos bens próprios de cada um dos cônjuges.

Podiam revestir duas modalidades: na primeira, os esposados estipulavam excluir-se reciprocamente na sucessão um do outro; na segunda, estipulavam que cada um deles e seus parentes ficariam excluídos da sucessão nos bens que um descendente comum houvesse herdado do outro.

A primeira modalidade raro se utilizava isoladamente, o que bem se compreende se nos lembrarmos de que a exclusão sucessória recíproca dos cônjuges, por si mesma, oferecia um diminuto interesse prático, pois na ordem da sucessão legítima o cônjuge sobrevivo só era chamado a suceder na falta de parentes colaterais até o $100^{\circ}$ grau do cômputo romano (Ord. Af. IV, 95̃, 1; Man. IV, 69; e Fil. IV, 94).

O mesmo se não pode dizer da segunda modalidade, que tinha, essa sim, um grande alcance prático, equivalendo a uma estipulação pactícia da regra paterna paternis, materna maternis ou direito de troncalidade. É preciso acentuar que a regra paterna parternis ou direito de troncalidade - que o direito costumeiro francês conheceu até ao fim do Ancien Régime e que o direito espanhol, em certas regiões de direito foraleiro, conservou até aos nossos dias nâo se manteve por muito tempo no direito português. Conhecida e bastante praticada no nosso direito medieval, foi das primeiras regras costumeiras a ceder perante o individualismo do direito romano renascido. Ainda há ves- 
tıgios dela na legislação dos nossos primeiros monarcas; mas a primeira codificação geral portuguesa - as Ordenaçôes Afonsinas - em meados do séc. $\mathrm{XV}$, já não lhe dá a minima aceitação.

Ora, apesar de banida da legislação, a ideia da conservação dos bens próprios no ramo familiar da sua procedência continuou sempre a merecer simpatias, não só nas classes nobres como nas próprias classes populares; e, daí, a frequência com que se estabelecia, nas convenções matrimoniais, que cada um dos cônjuges e seus parentes não poderiam suceder nos bens que um descendente comum houvesse recebido por sucessão do outro.

g) Finalmente, era também nos contratos antenupciais que mais largamente se praticavam os pactos renunciativos, sob a forma duma renúncia da filha dotada à legítima paterna.

As renúncias a uma sucessão não aberta, conforme já dissemos, eram admitidas pelo nosso direito em termos gerais, desde que acompanhadas de juramento; mas era a propósito do casamento das filhas, e em contrapartida dum dote, que tinham mais frequente aplicação. Ao contrário, porém do que sucedeu em certos direitos estrangeiros, designadamente no direito francês, os nossos jurisconsultos entendiam que, mesmo nesse caso, era necessário sempre serem acompanhadas de juramento para serem consideradas válidas.

7. Esta ampla liberdade de estipulação de pactos sucessórios nos contratos antenupciais manteve-se no direito português até a promulgação do Código Civil, em 1867, que, neste aspecto como em tantos outros, seguiu quase fielmente o modelo do Código de Napoleão.

Como é sabido, o direito intermediário, em França, condenou totalmente os pactos sucessórios, pela famosa lei de 17 de Nivose do ano II, admitindo como única excepção a do pacto de hereditate tertii dentro das condições previstas na constituição De quaestione, de Justiniano. Mas o Có- 
digo de Napoleão de 1804 teve de condescender algum tanto com a tradição; e, embora mantendo viva a hostilidade de princípio contra todos os pactos sobre sucessão futura, deixou sobreviver as instituições contratuais, sob a forma de "donations de biens à venir", quando celebradas no "contrat de mariage", banindo, porém, duma vez para sempre, os pactos renunciativos e os pactos de hereditate tertii.

A posição assim tomada pelo Código Civil francês foi a que serviu de padrão às codificações liberais da generalidade dos países latinos, com excepção do Código italiano de 1865 , que tomou uma posição de total intransigência contra a sucessão contratual, mantida, aliás, no Código de 1942. O Código Civil português, neste aspecto, é dos que mais de perto seguem o modelo napoleónico. Tal como o Código francês, condena in limine os pactos renunciativos e os pactos de hereditate tertii (art. 2042..$^{\circ}$ ); e admite, a titulo excepcional, as instituições contratuais, sob a forma de doações "mortis causa" para casamento (arts. 1166 e segs.; e 1175 e segs.). A única diferença sensível, em relação ao regime francês, reside em que, no Código de Napoleão, a "donation de biens à venir" só é válida se for celebrada no "contrat de. mariage", ao passo que, entre nós, essa exigência só diz respeito às doações feitas pelos esposados, um em favor do outro (art. 1166. ${ }^{\circ}$ ). Se é feita por terceiros em favor dos esposados, tanto pode ser celebrada no contrato antenupcial como em acto à parte, (art. $1175 .^{\circ}$ )

Referirei ainda, para terminar, que os modernos civilistas portugueses estão longe de mostrar pelos pactos sucessórios uma hostilidade tão marcada como aquela a que o Código Civil deu consagração legislativa. E é possível que o novo Código Civil português, cuja elaboração está prestes a ser concluída, venha alargar de novo a admissibilidade dos pactos sobre sucessão futura, embora dentro do campo restrito - que hoje parece definitivamente fixado nos direitos dos povos latinos - dos contratos antenupciais. 